\title{
Influence of steel fibers on the behavior of light weight concrete made from crushed clay bricks
}

\author{
Othman Hameed Zinkaah \\ Department of civil Engineering, College of Engineering, Almuthana University, Hilla, Iraq \\ Email address: \\ Al_azawy2001@yahoo.com \\ To cite this article: \\ Othman Hameed Zinkaah. Influence of Steel Fibers on the Behavior of Light Weight Concrete Made from Crushed Clay Bricks. \\ American Journal of Civil Engineering. Vol. 2, No. 4, 2014, pp. 109-116. doi: 10.11648/j.ajce.20140204.11
}

\begin{abstract}
The purpose of this study is to investigate the effects of steel fibers on some properties of light weight concrete. The coarse aggregate used in this study made from crushed clay bricks. Four proportions of steel fibers are used ( $0.25 \%$, $0.5 \%, 0.75 \%$, and $1 \%$ ) by volume of concrete, in addition, to reference mix (without steel fibers). The density obtained from experimental work was $1812 \mathrm{Kg} / \mathrm{m}^{3}$. The results showed that, in general, the adding of steel fibers led to increase the compressive strength of light weight concrete. The enhancement in compressive strength was about (17\%-43\%) at 7 days and (21\%-51\%) at 28 days as compared with reference mix. Also, it is deduced that, the proportion $(0.75 \%)$ of steel fibers is the optimum one. On the other hand, splitting tensile strength increased by about $62.62 \%, 33.76 \%, 17.27 \%$ and $5.93 \%$ for light weight concrete with $1 \%, 0.75 \%, 0.5 \%$ and $0.25 \%$ steel fibers by volume of concrete respectively. Furthermore, flexural strength improved by about $54.24 \%, 41.67 \%, 29.25 \%$ and $20.91 \%$ for light weight concrete with $1 \%, 0.75 \%, 0.5 \%$ and $0.25 \%$ steel fiber by volume of concrete respectively. Finally, the results indicated that, there are significant increases in static modulus of elasticity and absorption for mixes which have steel fibers as compared with others without steel fibers.
\end{abstract}

Keywords: Steel Fibers, Light Weight Concrete, Crushed Clay Bricks, Compressive Strength, Modulus of Elasticity, Absorption

\section{Introduction}

Structural lightweight aggregate concrete is defined as concrete which has a compressive strength in excess of $(17.2 \mathrm{MPa})$ at 28 days of age and has an equilibrium weight not exceeding $\left(1842 \mathrm{~kg} / \mathrm{m}^{3}\right)$ [1]. The low density lead to reduce dead load obtained by use of lightweight concrete and that reducing not only result in a decrease in cross section of columns, beams, walls and foundations, but also decrease the induced seismic loads and reduce the risk of earthquake damages to structures [2] since, the earthquake loads influencing the structures and buildings are proportional to the mass of those structures and buildings. Structural lightweight concrete mixtures can be designed to achieve similar strengths as normal weight concrete. The same is true for other mechanical and durability performance requirements. Structural lightweight concrete provides a more efficient strength-to-weight ratio in structural elements. In most cases, the marginally higher cost of the lightweight Concrete is offset by size reduction of structural elements, less reinforcing steel and reduced volume of concrete, resulting in lower overall cost. In buildings, structural lightweight concrete provides a higher fire-rated concrete structure [3], lower coefficient of thermal conductivity [4,5], improved durability properties [6]. The porosity of lightweight aggregate provides a source of water for internal curing of the concrete that provides continued enhancement of concrete strength and durability. This does not preclude the need for external curing. Structural lightweight concrete has been used for bridge decks, piers and beams, slabs and wall elements in steel and concrete frame buildings, parking structures, tilt-up walls, topping slabs and composite slabs on metal deck[7]. Light weight concrete was first introduced by Romans in the second century where the pantheon has been constructed using pumice, the most common type of aggregate used in that year [8]. The building of the pantheon of LWC material is still standing eminently in Rome until now for about 18 centuries. It shows that the lighter materials can be used in concrete construction and has economical advantage [9]. 


\section{Literature Review}

Many researchers investigated the effect of fibers on light weight concrete

Swamy \& Jojagha (1982) experimentally assessed material characteristics of steel fiber reinforced concrete (SFRC) and Steel fiber reinforced light weight concrete (SFRLC) under impact loads by means of a drop hammer test and a drop ball test in accordance with ACI 544.2R78. Three and four mixes were tested for normal weight and lightweight concrete, respectively. Both SFRC and SFRLC with $V_{f}=1 \%$ had greater impact resistance than those without steel fibers by a substantial degree up to a factor of 10. The effects of steel fiber shape and geometry were evident by the fact that the number of shocks needed to fail was 536 and 793 for paddle and hooked shapes, respectively, but much less (124 and 192) for crimped and plain shapes[10].

Balaguru \& Foden (1996) assess the applicability of discrete steel fibers for improving mechanical properties of normal-strength $(42 \mathrm{MPa})$ and high-strength $(62.1 \mathrm{MPa})$ lightweight concrete. The experimental programs consisted of third-point loading tests of prisms per ASTM C1018, splitting tensile and compressive strength tests of cylinders per ASTM C496/496M, and direct shear tests. In their experimental studies, it was found that the addition of steel fibers to lightweight concrete increased the compressive strength $\left(f_{\bar{c}}\right)$ by $30 \%$ to $40 \%$, splitting tensile strength $\left(f_{s p}\right)$ by $80 \%$ to $100 \%$, and modulus of elasticity $(E c)$ by $5 \%$ to $25 \%$. The improved mechanical properties were observed for all combinations of the fiber lengths $(30,50$, and $60 \mathrm{~mm})$ and steel fiber volume fractions $(0.55 \%, 0.75 \%, 0.9 \%$, and $1.1 \%)$ [11].

Higashiyama \& Banthia (2008) evaluated relations between shear and flexural toughness for both SFRC and SFRLC. Two fiber volume fractions (V $=0.5 \%$ and $1 \%)$ were selected for third-point loading tests in accordance with ASTM C1609 and for direct shear tests. The results indicated that for a given fiber type and volume fraction, steel fiber reinforced concrete (SFRC) exhibited better shear and flexural toughness properties than steel fiber reinforced light weight concrete (SFRLC) [12].

Libre, N. A., et al. (2011) improved the ductility of pumice lightweight aggregate concrete by incorporating hybrid steel and polypropylene fibers. The changes in mechanical properties and also bulk density and workability of pumice lightweight aggregate concrete due to the addition of hybrid steel and polypropylene fibers have been studied. The properties were investigated include bulk density and workability of fresh concrete as well as compressive strength, flexural tensile strength, splitting tensile strength and toughness of hardened concrete. A large increase in compressive and flexural ductility and energy absorption capacity due to the addition of steel fibers was observed. Polypropylene fibers, on the other hand, caused a minor change in mechanical properties of hardened concrete especially in the mixtures made with both steel and polypropylene fibers [13].

\section{Materials}

\subsection{Cement}

Table 1. Chemical Analysis of Cement

\begin{tabular}{|c|c|c|c|c|c|c|c|c|c|c|}
\hline Compound composition & $\mathrm{CaO}$ & $\mathrm{SiO} 2$ & Al2O3 & $\mathrm{Fe} 2 \mathrm{O} 3$ & SO3 & MgO & L.O.I & L.S.F. & I.R. & $\mathbf{C} 3 \mathbf{A}$ \\
\hline Percentage by weight & 63.2 & 18.9 & 3.8 & 4.6 & 1.5 & 1.7 & 1.9 & 0.9 & 0.4 & 2.32 \\
\hline Limit of ASTM Specif. C150-02a/2002 & ---- & --- & --- & ---- & $\leq 2.3$ & $\leq 6.0$ & $\leq 3.00$ & --- & $\leq 0.75$ & $\leq 5.0$ \\
\hline
\end{tabular}

Ordinary Portland cement type ALDOUH has been used in this investigation. The chemical analysis of cement are given in the Table (1) and (2), and these results completes with ASTM Specif. C150-02a/2002 [14]

\subsection{Fine Aggregate}

A normal weight washed sand with a $(4.75 \mathrm{~mm})$ maximum size is used as fine aggregates. The grading of the sand conformed to the requirement of ASTM C33-01 [15]. The sieve analysis results are given in Table (3).

Table 2. Physical properties of Cement

\begin{tabular}{lll}
\hline Physical properties & Test results & $\begin{array}{l}\text { Limit of ASTM Specif. } \\
\text { C150-02a/2002 }\end{array}$ \\
\hline $\begin{array}{l}\text { Initial setting (vicat) } \\
\text { Final setting (vicat) }\end{array}$ & $75 \mathrm{~min}$. & $45 \mathrm{~min}$.(Min) \\
$\begin{array}{l}\text { Compressive strength of } \\
\text { mortar (MPa) }\end{array}$ & $165 \mathrm{~min}$. & $375 \mathrm{~min}$. (Max.) \\
3-day & 19.5 & 15 (Min.) \\
7-day & 29.3 & 21 (Min.) \\
\hline
\end{tabular}

Table 3. Grading of fine aggregate

\begin{tabular}{lll}
\hline Sieve size & Cumulative Passing \% & Limit of ASTM C33-01 \\
\hline $9.5 \mathrm{~mm}$ & 100.00 & 100 \\
$4.75 \mathrm{~mm}$ & 95.58 & $95-100$ \\
$2.36 \mathrm{~mm}$ & 73.50 & $80-100$ \\
$1.18 \mathrm{~mm}$ & 70.03 & $50-85$ \\
$600 \mu \mathrm{m}$ & 51.50 & $25-60$ \\
$300 \mu \mathrm{m}$ & 16.40 & $5-30$ \\
$150 \mu \mathrm{m}$ & 2.14 & $0-10$ \\
\hline
\end{tabular}

\subsection{Crushed Bricks as Light Weight Coarse Aggregate}

In this research a crushed hole-clay bricks with dimensions $\left(235^{*} 115^{*} 75\right) \mathrm{mm}$ were used as coarse light weight aggregate .The bricks crushed and graded according to ASTM C330-04[16] for light weight aggregate with 19 $\mathrm{mm}$ maximum size. Bricks before crushing have the compressive strength $(12.3 \mathrm{MPa})$ and $(22.4 \%)$ absorption. 
Table (4) and (5) shows the grading and physical properties of coarse LWA respectively.

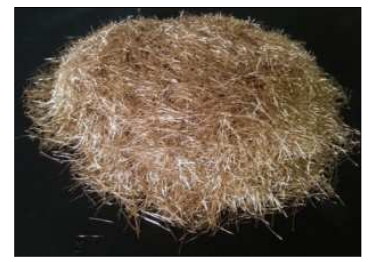

Plate 1. Steel fibers

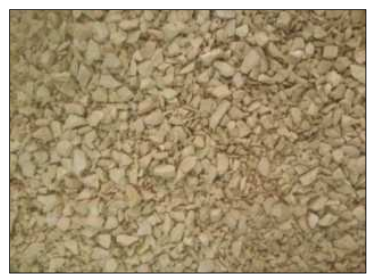

Plate 2. Light weight coarse aggregate

Table 4. Grading of light weight coarse aggregate

\begin{tabular}{lll}
\hline Sieve size & Cumulative Passing \% & Limits of ASTM C330-04 \\
\hline $25 \mathrm{~mm}$ & 100 & 100 \\
$19 \mathrm{~mm}$ & 100 & $90-100$ \\
$9.5 \mathrm{~mm}$ & 40 & $10-50$ \\
$4.75 \mathrm{~mm}$ & 10 & $0-15$ \\
$75 \mu \mathrm{m}$ & 2 & $0-10$ \\
\hline
\end{tabular}

Table 5. Physical properties of light weight coarse aggregate

\begin{tabular}{lll}
\hline Property & Test results & Limits of ASTM C330-04 \\
\hline $\begin{array}{l}\text { Bulk density } \\
\left(\mathrm{Kg} / \mathrm{m}^{3}\right)\end{array}$ & 852 & 880 \\
Absorption & $27.4 \%$ & --- \\
Specific gravity & 1.75 & ---- \\
\hline
\end{tabular}

\subsection{Steel Fibers}

The steel fibers used in this test program were straight steel fibers; Table (6) shows the properties of steel.

Table 6. Properties of steel fiber

\begin{tabular}{ll}
\hline Property & Specifications \\
\hline Density & $7800 \mathrm{~kg} / \mathrm{m}^{3}$ \\
Tensile strength & $2850 \mathrm{MPa}$ \\
Length & $15 \mathrm{~mm}$ \\
Diameter & $0.2 \mathrm{~mm}$ \\
Aspect ratio & 75 \\
\hline
\end{tabular}

\subsection{High-Range Water Reducing Admixture (Superplasticizer)}

Sika viscocrete-5930 is used to reduce the water and to get higher compressive strength. It is a third generation Superplasticizer for concrete and mortar and meets the requirements for super plasticizer according to ASTM-C494 Types G and F and BS EN 934 part 2: 2001.

\section{Mix Proportions}

The reference mixture (A) is designed according to the Standard Practice for Selecting Proportions for Structural Lightweight Concrete (ACI 211.2-98) ${ }^{(1)}$. A series of five concrete mixtures were made including reference mixture(A), while other four mixtures contain steel fibers there are $(1 \%, 0.75 \%, 0.5 \%$, and $0.25 \%)$ for mixes $(\mathrm{B}, \mathrm{C}, \mathrm{D}$ and E) by volume of concrete respectively. Superplasticizer was added to give the slump within (200250 ) for all mixtures. The light weight coarse aggregate and fine aggregate was flooded with water, $24 \mathrm{~h}$ prior to mixing, then this was drained before mixing to get saturated surface dry aggregate (S.S.D). Table (7) shows the mixture proportions of light weight concrete.

Table 7. Details of the mixtures

\begin{tabular}{lllllll}
\hline Mix & Percent of S.F by volume of concrete & Cement $\left(\mathbf{K g} / \mathbf{m}^{3}\right)$ & Sand $\left(\mathbf{K g} / \mathbf{m}^{3}\right)$ & Aggregate $\left(\mathbf{K g} / \mathbf{m}^{3}\right)$ & W/C & S.P \% of cement \\
\hline A & 0 & 385 & 500 & 690 & 0.3 & 0.6 \\
B & 1 & 385 & 500 & 690 & 0.3 & 0.80 \\
C & 0.75 & 385 & 500 & 690 & 0.3 & 0.75 \\
D & 0.5 & 385 & 500 & 690 & 0.3 & 0.70 \\
E & 0.25 & 385 & 500 & 690 & 0.3 & 0.65 \\
\hline
\end{tabular}

* S.F: Steel Fibers, * S.P: Superplasticizer

\section{Mixing of Concrete}

Firstly, the quantities of gravel and sand were placed in a concrete mixer and dry mixed for $1 \mathrm{~min}$. Secondly, the cement is spread and dry mixed for $1 \mathrm{~min}$. After which, fibers were slowly added by hand spraying, while the mix was rotating. Mixing was continued for 3 minutes to encourage a uniform distribution of fibers throughout the concrete. Lastly, adding of water and the Superplasticizer to the mix. The mixing time was ranging between (2-3) minutes to get a uniform mix without segregation.

\section{Casting, Compactions and Curing}

The freshly mixed fiber-reinforced concrete is fed into the molds, the molds were lightly coated with mineral oil 
before use, according to ASTM C 192-88 [17], concrete casting was carried out in different layer each layer of 50 $\mathrm{mm}$. Each layer was compacted by using a vibrating table for (15-30) second until no air bubbles emerged from the surface of the concrete, and the concrete is leveled off smoothly to the top of the molds. Then the specimens were kept covered in the laboratory for about (24) hours. After that the specimens remolded carefully, marker and immersed in water until the age of test.

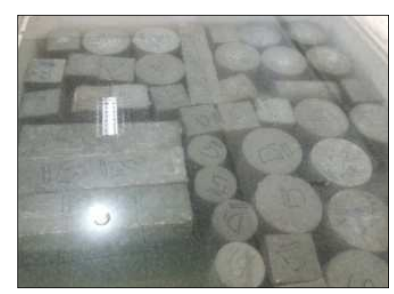

Plate 3. Curing of light weight concrete

\section{Testing of Concrete}

To investigate the behavior of light weight concrete with steel fibers the following specimens were cast for each mix.

- Six $(100 \mathrm{~mm})$ cubes to measure the compressive strength at 7 and 28 days according to BS 1881 part 116:1989[18].

- Two $(100 * 200 \mathrm{~mm})$ cylinders to conduct the splitting tensile strength at 28 days, accordance to ASTM C 496-86 [19].

- Two $(100 \times 100 \times 400 \mathrm{~mm})$ prisms to evaluate the flexural strength at 28 days, according to ASTM C 78 (2002) [20].

-Two $(150 * 300 \mathrm{~mm})$ cylinders to conduct the splitting tensile strength at 28 days, according ASTM C 469 (2002) [21].

- Furthermore, two $100 \mathrm{~mm}$ cubes were cast to investigate the water absorption according to B.S. ASTM C 642 [22].

\section{Results and Discussion}

\subsection{Equilibrium Density of Light Weight Concrete}

To measure the equilibrium density according ACI 211.2-98[1], remove the cylinders have dimensions $(150 * 300) \mathrm{mm}$ from their curing condition on the seventh day after molding and immerse in water at $\left(23 \pm 2{ }^{\circ} \mathrm{C}\right)$ for $24 \mathrm{~h}$. Measure the apparent mass of the cylinders while suspended and completely submerged in water and record as (C). Remove from the water and allow to drain for $1 \mathrm{~min}$ by placing the cylinder on a coarser cloth. Remove visible water with a damp cloth, determine the mass and record as (B). Dry the cylinders with all surfaces exposed, in a controlled humidity until the mass of the specimen changes not more than $0.5 \%$ and record as (A). The equilibrium density of the light weight concrete can be calculated from the following equation.

$$
\mathrm{Em}=(\mathrm{Ax} 997) /(\mathrm{B}-\mathrm{C})
$$

Where:

$\mathrm{Em}=$ measured equilibrium density, $\mathrm{kg} / \mathrm{m} 3$

$\mathrm{A}=$ mass of cylinder as dried, $\mathrm{kg}$ (lb)

$\mathrm{B}=$ mass of saturated surface-dry cylinder, $\mathrm{kg}$

$\mathrm{C}=$ apparent mass of suspended-immersed cylinder, $\mathrm{kg}$

The equilibrium density of light weight concrete in this research equal to $1812 \mathrm{Kg} / \mathrm{m}^{3}$ and that satisfied the requirements of ACI committee 211.2-98; state that, the equilibrium weight not exceeding $\left(1842 \mathrm{~kg} / \mathrm{m}^{3}\right)$.

\subsection{Compressive Strength}

Values of compressive strength for all mixes are shown in Table (8) and Figure (1) at 7 and 28 days, results demonstrated that in general, all concrete specimens exhibited an increase in compressive strength with increase the percent of steel fibers. The percent of increasing in compressive strength at 7 days about $(27.18 \%, 43 \%$, $30.32 \%$, and $17.48 \%$ ) for $(1 \%, 0.75 \%, 0.5 \%$, and $0.25 \%)$ steel fibers respectively. While in 28 days, adding ( $1 \%$, $0.75 \%, 0.5 \%$, and $0.25 \%$ ) steel fibers lead to increasing in compressive strength by about $(30.33 \%, 51.73 \%, 33.79 \%$, and $21.26 \%$ ) respectively. It can be seen that the increase in compressive strength of light weight steel fiber concrete at 28 days was greater than their corresponding compressive strength at 7 days. Such increase in compressive strength was attributed to the intensive product of hydration process around the steel fibers and in voids of concrete [23].

From Figure (1) it may also be concluded that the addition of steel fibers up to $0.75 \%$ of concrete volume improved the compressive strength of light weight concrete due to the better mechanical bond strength between the fibers and the cement matrix which delays micro-cracks formation [24]. However, Adding more steel fibers up to $1 \%$ of concrete volume reduces the increasing in the compressive strength as compared with $0.75 \%$ but it remain higher than the reference mix and this is attributed to the voids introduction in the mix due to excessive fiber content that may lead to reduction in bonding and disintegration[25].

Table 8. Compressive strength at 7 and 28 days

\begin{tabular}{lllll}
\hline Mix & $\begin{array}{l}\text { Compressive strength } \\
\text { MPa-7 days }\end{array}$ & $\begin{array}{l}\text { \% Increase in compressive } \\
\text { strength-7 days }\end{array}$ & $\begin{array}{l}\text { Compressive strength } \\
\text { MPa-28 days }\end{array}$ & $\begin{array}{l}\text { \% Increase in compressive } \\
\text { strength-7 days }\end{array}$ \\
\hline A-0.00\%S.F & 22.66 & ------ & 29.77 & $-37 .--17$ \\
B-1.00\%S.F & 28.82 & 27.18 & 45.17 & 30.33 \\
C-0.75\%S.F & 32.41 & 43.00 & 39.83 & 33.79 \\
D-0.50\%S.F & 29.53 & 30.32 & 36.1 & 21.26 \\
E-0.25\%S.F & 26.32 & 17.48 & \\
\hline
\end{tabular}




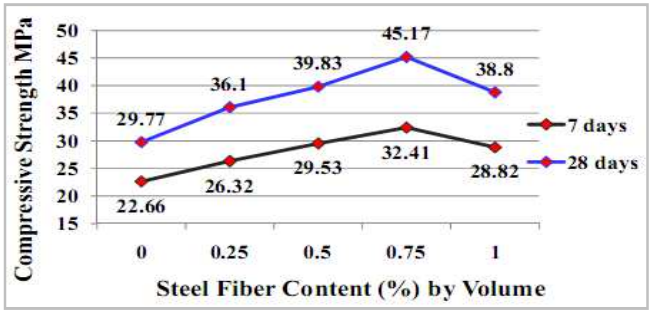

Figure 1. Compressive strength at 7 and 28 days

\subsection{Splitting Tensile Strength}

The results of splitting tensile strength for the lightweight concrete mixes are shown in Table (9) and plotted in Figure (2). It can be concluded that the inclusion of steel fibers in concrete mix cause a considerable increase in splitting tensile strength relative to reference mix (without fibers). Splitting tensile strength increases as the fiber volume fraction increases. However, The increasing in splitting tensile strength of light weight steel fiber concrete (LWSFC) relative to reference concrete at 28 days were $62.62 \%, 33.76 \%, 17.27 \%$ and $5.93 \%$ for

LWSFC with $1 \%, 0.75 \%, 0.5 \%$ and $0.25 \%$ steel fiber by volume of concrete respectively, Figure (3). This increasing may be due to the excellent mechanical anchorage of steel fibers at their surface which leads to high bond strength between the fibers and the matrix.

Table 9. Splitting tensile strength at 28 days

\begin{tabular}{lll}
\hline Mix & $\begin{array}{l}\text { Splitting strength } \\
\text { MPa-28 days }\end{array}$ & $\begin{array}{l}\text { \% Increase in } \\
\text { splitting strength }\end{array}$ \\
\hline A-0.00\%S.F & 3.88 & ------ \\
B-1.00\%S.F & 6.31 & 62.63 \\
C-0.75\%S.F & 5.19 & 33.76 \\
D-0.50\%S.F & 4.55 & 17.27 \\
E-0.25\%S.F & 4.11 & 5.93 \\
\hline
\end{tabular}

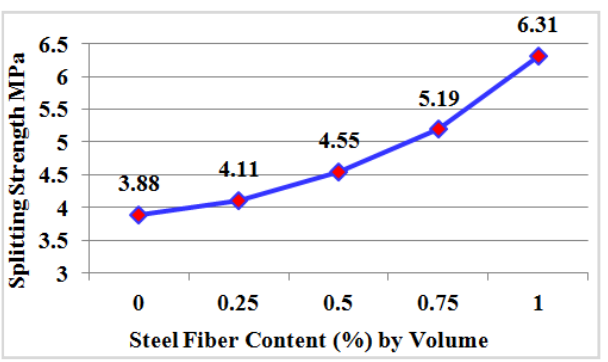

Figure 2. Splitting tensile strength at 28 days

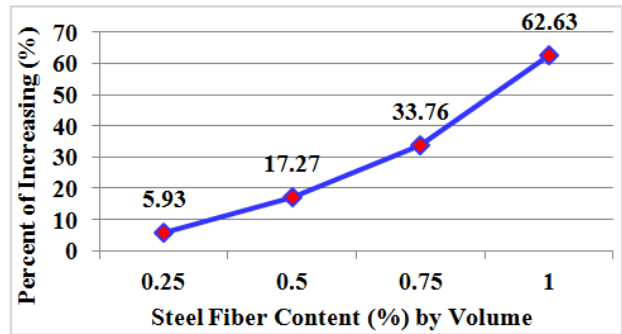

Figure 3. Relationship between the steel fibers content and increasing in splitting tensile strength

\subsection{Flexural Strength}

The test results of the flexural strength are reported in Table (10) and Figure (4). The results indicated that in general, all types of concrete specimens exhibited continued increase in flexural strength with increasing in steel fibers. The increase in flexural strength for light weight concrete with steel fiber relative to reference concrete mix were $20.91 \%, 29.25 \%, 41.67 \%$ and $54.24 \%$ for light weight concrete with $0.25 \%, 0.5 \%, 0.75 \%$ and $1 \%$ steel fiber by volume of concrete respectively. This behavior is mainly attributed to the role of steel fiber in releasing fracture energy around crack tips which is required to extent crack growing by transferring stress from one side to another side. Also this behavior is due to the increase in crack resistance of the composite and the ability of fibers to resist forces after the concrete matrix has cracked [23].

Table 10. Flexural strength at 28 days

\begin{tabular}{lll}
\hline Mix & $\begin{array}{l}\text { Flexural strength } \\
\text { MPa-28 days }\end{array}$ & $\begin{array}{l}\text { \% Increase in } \\
\text { flexural strength }\end{array}$ \\
\hline A-0.00\%S.F & 6.60 & ------- \\
B-1.00\%S.F & 10.18 & 54.24 \\
C-0.75\%S.F & 9.35 & 41.67 \\
D-0.50\%S.F & 8.53 & 29.24 \\
E-0.25\%S.F & 7.98 & 20.91 \\
\hline
\end{tabular}

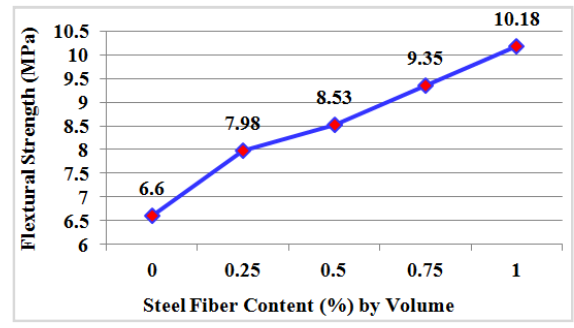

Figure 4. Flexural strength at 28 days

\subsection{Static Modulus of Elasticity}

The modules of elasticity results for all mixes are presented in Table (11). While, the relationship between steel fibers proportions and static modulus of elasticity for crushed brick lightweight concrete are shown in Figure (5). It can be seen that, adding $0.75 \%$ steel fibers led to maximum increasing in static modulus of elasticity and that improving about $12.58 \%$. This is probably due to this value of steel fibers produce higher compressive strength and thus a higher modulus of elasticity. In the other hand adding $0.25 \%, 0.5 \%$, and $1 \%$ steel fiber led to increasing modulus of elasticity by about $4.62 \%, 7.61 \%$, and $8.17 \%$ respectively. It can be concluded that the static modulus of elasticity about $\left(3500 \sqrt{f_{c}^{\prime}}\right)$.

Where: $\mathrm{fc}^{\prime}=$ ultimate strength of concrete in $\mathrm{MPa}$ (cylinder test) 
Table 11. Modulus of elasticity at 28 days

\begin{tabular}{lll}
\hline Mix & $\begin{array}{l}\text { Modulus of elasticity } \\
\text { GPa-28 days }\end{array}$ & $\begin{array}{l}\text { \% Increase in } \\
\text { Modulus of elasticity }\end{array}$ \\
\hline A-0.00\%S.F & 19.71 & ------ \\
B-1.00\%S.F & 21.32 & 8.17 \\
C-0.75\%S.F & 22.19 & 12.58 \\
D-0.50\%S.F & 21.21 & 7.61 \\
E- $0.25 \%$ S.F & 20.62 & 4.62 \\
\hline
\end{tabular}

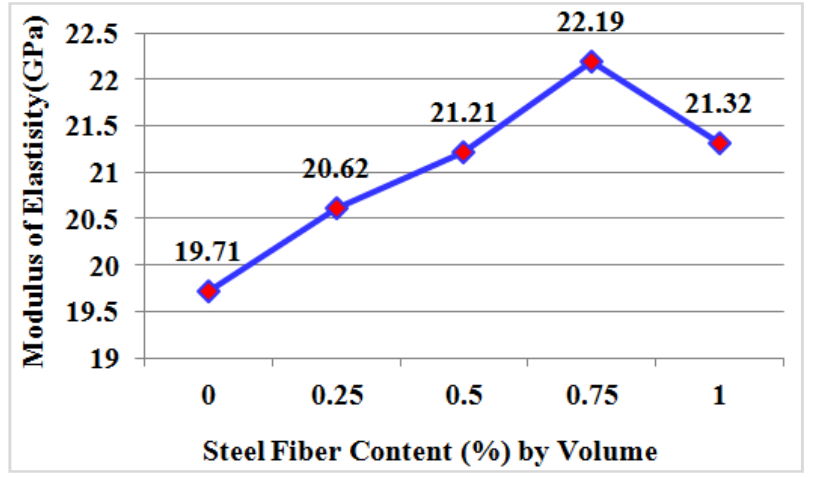

Figure 5. Modulus of elasticity at 28 days

\subsection{Water Absorption}

The steps of absorption test as following. First, the specimens are dried in an oven 24 hours at a temperature of $100^{\circ}$ to $110 \mathrm{C}^{\circ}$, after removing each specimen from the oven, allow it to cool in dry air to a temperature of 20 to $25^{\circ} \mathrm{C}$ and determine the mass (until the difference in mass after 24 hours in oven is less than $0.5 \%$ ). The dry mass is called MD. Second, the concrete specimens are immersed in water until the change in mass during 24 hours is less than $0.5 \%$. The saturated mass obtained is called MS. The water absorption by immersion (W) is expressed as the water up take relative to the dry mass.
$\mathrm{W}=(\mathrm{MS}-\mathrm{MD}) / \mathrm{MD}$. The results of water absorption test with proportions of steel fibers are given Table (12) and Figure (6). It is clearly shown that adding steel fibers have the direct effect on the water absorption of the light weight concrete. The water absorption of all specimens increases by adding steel fibers by. The increase in water absorption for light weight concrete with steel fiber relative to reference concrete mix ranged from $(1.31 \%)$ to $(9.24 \%)$ depending on content of steel fibers. It is believed that, the increasing in water absorption is due to the interlocking of steel fibers which cause spaces, and these spaces represent suitable locations for water diffusion.

Table 12. Water absorption at 28 days

\begin{tabular}{lll}
\hline Mix & $\begin{array}{l}\text { Water absorption } \\
\text { at } 28 \text { days }(\%)\end{array}$ & $\begin{array}{l}\text { \% Increase in Water } \\
\text { absorption }\end{array}$ \\
\hline A- $0.00 \%$ S.F & 12.23 & ----- \\
B- $1.00 \%$ S.F & 13.36 & 9.24 \\
C-0.75\%S.F & 12.87 & 5.23 \\
D-0.50\%S.F & 12.56 & 2.70 \\
E-0.25\%S.F & 12.39 & 1.31 \\
\hline
\end{tabular}

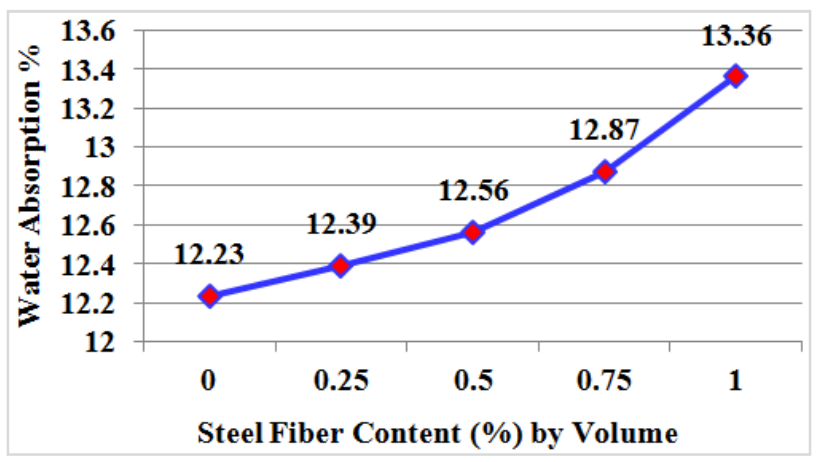

Figure 6. Water absorption at 28 days
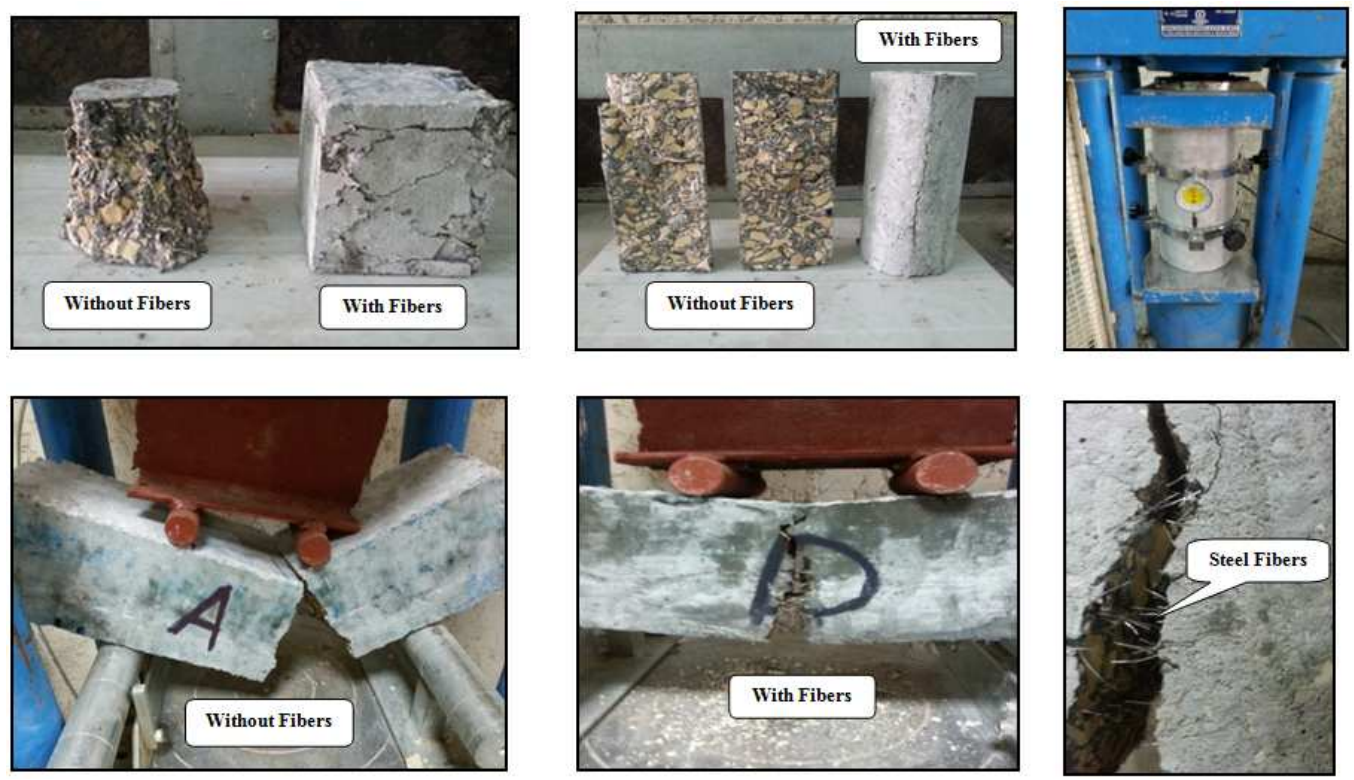

Plate 4. Mode of light weight concrete

It can be noticed from plate 4 that, non-fibered specimen suddenly failed in a brittle manner and separated into two parts, while fiber light weight concrete specimens have many cracks before the failure. 


\section{Conclusions}

1. This study concluded that, crushed bricks as coarse aggregate and steel fibers can be used together to produce light weight concrete has acceptable properties and has equilibrium density equal to $1812 \mathrm{Kg} / \mathrm{m}^{3}$.

2. In general, the compressive strength of light weight concrete increase with adding steel fibers, that increases in compressive strength varied (17\%-43\%) at 7 days and $(21 \%-51 \%)$ at 28 days as compared with reference mix.

3. The experimental work indicated that, the optimum proportion of steel fibers act on compressive strength was $(0.75 \%)$, furthermore, increase steel fibers from $(0.75 \%)$ to $(1 \%)$ by volume of concrete caused decrease in compressive strength from $(43 \%)$ to $(27 \%)$ in 7 days, and from $(51 \%)$ to $(30 \%)$ in 28 days as compared with reference mix (without steel fibers).

4. The splitting tensile strength of light weight concrete increased when adding steel fibers. The increasing in splitting tensile strength of light weight steel fiber concrete (LWSFC) relative to reference concrete at 28 days were $62.62 \%$, $33.76 \%, 17.27 \%$ and $5.93 \%$ for LWSFC with $1 \%$, $0.75 \%, 0.5 \%$ and $0.25 \%$ steel fiber by volume of concrete respectively.

5. Using steel fibers in light weight concrete led to significant effect on flexural strength. The increase in flexural strength for light weight concrete with steel fiber relative to reference concrete mix were $20.91 \%, 29.25 \%, 41.67 \%$ and $54.24 \%$ for light weight concrete with $0.25 \%, 0.5 \%, 0.75 \%$ and $1 \%$ steel fiber by volume of concrete respectively.

6. Steel fibers improved the static modulus of elasticity by about (4\%-12\%) depends on steel fibers content. The superior present of steel fibers is $(0.75 \%)$ that gives higher static modulus of elasticity better than (1\%) steel fibers.

7. There are an increasing in water absorption for light weight steel fibers concrete compared with reference mix, and that increases varied $(1.31 \%$ $9.24 \%$ ) depending on the ratio of steel fibers.

\section{References}

[1] ACI committee 211, "Standard practice for selecting proportions for structural lightweight concrete" (ACI 211.298) (Reapproved 2004), ACI manual of concrete practice, pp. $1-20$.

[2] Topcu IB. "Semi-lightweight concretes produced by volcanic slags". Cem Concr Res 1997; 27:15-21.

[3] Bilodeau A, Kodur VKR, Hoff GC. "Optimization of the type and amount of polypropylene fibers for preventing the spalling of lightweight concrete subjected to hydrocarbon fire". Cem Concr Compos 2004; 26(2):163-74.
[4] Al-Jabri KS, Hago AW, Al-Nuaimi AS, Al-Saidy AH. "Concrete blocks for thermal insulation in hot climate". Cem Concr Res 2005;35:1472-9.

[5] Uysal H, Demirboga R, Remzi S, Gul R. "The effects of different cement dosages, slumps, and pumice aggregate ratios on the thermal conductivity and density of concrete". Cem Concr Res 2004;34:845-8.

[6] Hwang CL, Hung MF. "Durability design and performance of self-consolidating lightweight concrete". Constr Build Mater 2005;19:619-26.

[7] NRMCA, CIP 36, "Concrete in Practice, Structural Light Weight Concrete", National Ready Mixed Concrete Association, 2003, P.P. 1-2.

[8] Mohd, R.S. ,"Lightweight Concrete" ,M.SC. in Civil. Eng. University of technology Malaysia ,1997. P. 1.

[9] Hjh, KM., Mohamad, S.F., and Norpadzlihatum, M., "Study of Lightweight Concrete". http://www.4shared.com

[10] Balaguru, P. \& Foden, A. 1996. "Properties of Fiber Reinforced Structural Lightweight Concrete". ACI Structural Journal, 93 (1): 62-78.

[11] Swamy, R.N. \& Jojagha, A.H. 1982. "Impact Resistance of Steel Fibre Reinforced Lightweight Concrete". International Journal of Cement Composites and Lightweight Concrete, 4 (4): 209-220.

[12] Higashiyama, H. \& Banthia, N. 2008. "Correlating Flexural and Shear Toughness of Lightweight Fiber-Reinforced Concrete". ACI Materials Journal, 105 (3): 251-257.

[13] Libre N. A., Shekarchi M., Mahoutian, \& Soroushian P., "Mechanical properties of hybrid fiber reinforced lightweight aggregate concrete made with natural pumice", Construction and Building Materials Journal, 25(2011): 2458-2464.

[14] ASTM C 150-02a; "Standard Specification for Portland Cement", Annual Book of ASTM Standards, Vol. 04. 02, 2002.

[15] ASTM C 33 - 01. "Standard Specification for Concrete Aggregates". "Annual book of ASTM standards, 2001, pp. $1-8$.

[16] ASTM C 330-04, "Standard specification for lightweight aggregate for structural concrete "Annual book of ASTM standards, pp. 1-4.

[17] ASTM C192-88 "Standard Practice for Making and Curing Test Specimens in the Laboratory". Animal Book of ASTM Standard, Philadelphia, Vol.04-02, 1989, pp. 112-118.

[18] B.S. 1881, part 116, "Method of Determination of Compressive Strength of Concrete Cubes", British Standards Institution, 1989.

[19] ASTM C496-86 "Standard Test Method for Splitting Tensile Strength of Cylindrical Concrete Specimens", Annual Book of ASTM Standard, Philadelphia, Vol. 04-02, 1989, pp. 259262.

[20] ASTM C78-84 "Standard Test Method for Flexural Strength of Using Simple Beam with Third-Point Loading", Annual Book of ASTM Standard, Philadelphia, Vol. 04-02, 1989, pp.32-34. 
[21] ASTM C469, "Standard Test Method for Static Modulus of Elasticity and Poisson's Ratio of Concrete in Compression", Vol. 4, 2002, pp.1-5.

[22] ASTM C642-06," Standard Test Method for Density, Absorption, and Voids in Hardened Concrete", Annual book of ASTM Standard, pp.1-3.

[23] Salih, S. A., Rejeb, S. K., and Najem, K. B. "The Effect of Steel Fibers on the Mechanical Properties of high
Performance Concrete" 2005 Al-Rafidain Engineering Vol.13 No.4.

[24] Dawood ET, M. "Proportioning of crushed brick concrete reinforced by palm fibre". Journal of Materials Sciences and Engineering with Advanced Technology. 2010; 2(1):77-96.

[25] Dawood ET, Ramli M. "Study the effect of using palm fiber on the properties of high strength flowable mortar", CI Premier: 34th OWICs papers, Singapore. 2009; 93-101. 